Kyoto University,

Graduate School of Economics

Discussion Paper Series

\title{
Effect of Capitalizing Operating Leases on Credit Ratings:
}

Evidence from Japan

Masaki Kusano

Discussion Paper No. E-16-016

Graduate School of Economics

Kyoto University

Yoshida-Hommachi, Sakyo-ku

Kyoto City, 606-8501, Japan

March, 2017 


\title{
Effect of Capitalizing Operating Leases on Credit Ratings: Evidence from Japan*
}

\author{
Masaki Kusano \\ Graduate School of Economics, Kyoto University \\ Yoshida-honmachi, Sakyo-ku, Kyoto, 606-8501, Japan \\ kusano@econ.kyoto-u.ac.jp
}

March 13, 2017

Journal of International Accounting; Auditing and Taxation (forthcoming)

\begin{abstract}
The purpose of this study is to examine the effects of constructively capitalizing operating leases on credit ratings in Japan. In particular, this study investigates whether and how a credit rating agency considers operating lease information when determining credit ratings. First, this study shows that constructively capitalized operating leases are associated with credit ratings. Second, this study finds that the associations between credit ratings and operating leases versus finance leases are not substantially different. However, when operating lease disclosures are less reliable, this study finds that operating leases are not associated with credit ratings and that the risk relevance of operating leases is substantially different from that of finance leases. This study reports that the reliability of accounting information has significant effects on the risk relevance of operating leases. These results indicate that a credit rating agency considers operating lease information in determining credit ratings to the extent that this information is reliable. This study contributes to the literature on the usefulness of operating lease disclosures and to the discussions on the global convergence of accounting standards.
\end{abstract}

JEL Classification: M41, M48

Keywords: Constructive Capitalization, Operating Leases, Risk Relevance, Reliability

\footnotetext{
* Acknowledgements: I gratefully appreciate the helpful comments and suggestions received from the editor and two anonymous referees. I also appreciate Rating and Investment Information Inc. for permitting me to use credit ratings data. I gratefully acknowledge the financial support from the Japan Society for the Promotion of Science Grant-in-Aid for Scientific Research (C) (JSPS KAKENHI Grant Numbers 26380607 and 26380625).
} 


\section{Introduction}

The purpose of this study is to examine whether and how capital market participants use off-balance sheet operating leases when assessing firms' credit risk in Japan. In particular, this study investigates the risk relevance of operating leases using credit ratings as a proxy for the cost of debt. Furthermore, this study analyzes the effects of the reliability of accounting information on the risk relevance of operating leases.

The International Accounting Standards Board (IASB) and the Financial Accounting Standards Board (FASB) proposed a new lease accounting model that required lessees to recognize almost all leases on their balance sheet (IASB, 2009, 2010, 2013). The current lease accounting models under International Financial Reporting Standards (IFRS) (IAS 17) (IASC, 1982) and U.S. Generally Accepted Accounting Principles (GAAP) (ASC 840/SFAS 13) (FASB, 1976) classify leases as either finance (capital) leases or operating leases and account for them differently. Both accounting standard setters assume that operating leases are similar to finance leases from an economic perspective; however, current accounting standards do not require lessees to recognize operating leases on their balance sheet. Because existing accounting standards create asymmetry and inaccuracy of information in the market, the IASB and the FASB criticized them and finally issued new lease accounting standards that required lessees to recognize both types of leases on their balance sheet (FASB, 2016; IASB, 2016).

Capitalization of operating leases has been proposed for a long time (e.g., Lorensen, 1992; McGregor, 1996; Myers, 1962; Nailor \& Lennard, 2000). Prior literature examines whether capital market participants sufficiently understand disclosed operating leases and consider them in their decision making (Barone, Birt, \& Moya, 2014; Lipe, 2001; Spencer \& Webb, 2015). In particular, previous studies investigate the associations between operating leases and equity or credit risk and find the risk relevance of operating leases (Altamuro, Johnston, Pandit, \& Zhang, 2014; Andrade, Henry, \& Nanda, 2014; Beattie, Goodacre, \& Thomson, 2000; Bratten, Choudhary, \& Schipper, 2013; Chu, Levesque, Mathieu, \& Zhang, 2008; Dhaliwal, Lee, \& Neamtiu, 2011; Ely, 1995; Ge, Imhoff, 
\& Lee, 2008; Imhoff, Lipe, \& Wright, 1993; Lim, Mann, \& Mihov, 2014; Sengupta \& Wang, 2011). These studies show that constructively capitalized operating leases are risk relevant mainly using a sample of firms in the U.S.

However, operating lease disclosures under Japanese GAAP are less informative than those under U.S. GAAP and IFRS. In Japan, regarding operating leases, future minimum lease payments divided between within one year and more than one year out are only disclosed in the notes to financial statements. Compared with recognized items in financial statements, capital market participants face higher information processing costs for disclosed information in the notes (Barth, Clinch, \& Shibano, 2003; Schipper, 2007). The risk relevance of operating leases depends on the extent to which disclosed information has been processed by various capital market participants. In fact, previous studies report that sophisticated investors lower information processing costs, thereby resulting in a complete understanding of disclosed items (Michels, 2017; Müller, Riedl, \& Sellhorn, 2015; Yu, 2013). In particular, prior literature shows that one of the sophisticated capital market participants, namely a credit rating agency, considers operating lease disclosures when assessing firms' credit risk (Kraft, 2015; Lim et al., 2014; Sengupta \& Wang, 2011). However, in Japan, because operating lease information is not sufficiently disclosed, even sophisticated capital market participants might face higher information processing costs to understand disclosed operating lease information. Thus, disclosed operating leases may not provide useful information to capital market participants. Accordingly, using a sample of Japanese firms, it is necessary to empirically investigate whether and how a credit rating agency considers operating lease disclosures when determining credit ratings. Employing this unique setting, this study analyzes the effects of constructively capitalized operating leases on credit ratings.

The first objective of this study is to examine whether a credit rating agency understands disclosed operating leases and uses them when assessing firms' credit risk. When operating lease information is not sufficiently disclosed in the notes to financial statements, capital market participants may have difficulty understanding operating 
lease disclosures. Credit rating agencies are more sophisticated at processing financial information to evaluate firms' credit risk. Thus, this study investigates whether a credit rating agency considers disclosed operating lease information when determining credit ratings and shows that constructively capitalized operating leases are risk relevant when assessing credit risk.

Even though operating leases are risk relevant, examining whether they have the same risk relevance as finance leases for explaining credit risk is necessary because the possibility exists that the reliability of accounting information differs between finance leases and operating leases. The amounts of finance lease obligations are reported in financial statements, including the notes; however, the value of operating leases is estimated using a constructive capitalization method with footnote information. Accordingly, the second objective of this study is to investigate whether a credit rating agency processes operating leases and finance leases similarly when determining credit ratings. This study reports that the risk relevance of operating leases is not substantially different from the risk relevance of finance leases.

However, after the adoption of Statement No. 13, Accounting Standard for Lease Transactions (ASBJ, 2007a), this study finds that operating leases are not associated with credit ratings and that the associations between credit ratings and operating leases versus finance leases are substantially different. In response to the adoption of Statement No. 13, Japanese firms are more likely to use operating leases (Kusano, Sakuma, \& Tsunogaya, 2015), resulting in a lengthening of operating leases' contract lifetimes. Because this study estimates operating lease obligations using footnote information, longer lease contract lifetimes induce measurement errors with respect to operating leases, thereby decreasing the reliability of accounting information. It is predicted that the measurement errors of operating lease obligations decrease the risk relevance for explaining credit risk. Thus, the third objective of this study is to analyze how a credit rating agency considers operating lease disclosures when they are less reliable. This study shows that the reliability of accounting information has significant effects on the risk relevance of operating leases 
when determining credit ratings.

This study makes two contributions to the accounting literature and accounting standards setting. First, this study contributes to the literature on the usefulness of the accounting information disclosed in the notes to financial statements. Previous studies examine the associations between operating leases and the costs of equity and debt mainly using a sample of firms in the U.S. (Altamuro et al., 2014; Andrade et al., 2014; Bratten et al., 2013; Chu et al., 2008; Dhaliwal et al., 2011; Ely, 1995; Ge et al., 2008; Imhoff et al., 1993; Lim et al., 2014; Sengupta \& Wang, 2011). However, regarding operating leases, Japanese disclosures are less informative compared with disclosures required by U.S. GAAP and IFRS. Even though operating lease disclosures are insufficient, this study shows that a credit rating agency considers operating lease information in determining credit ratings to the extent that this information is reliable. These results indicate that the reliability of accounting information is critically important when providing useful accounting information to capital market participants. In particular, my findings suggest that even sophisticated capital market participants do not fully understand disclosed information when it is less reliable.

Second, this study has implications for discussions on the global convergence of accounting standards. Since existing accounting standards do not provide complete operating lease information in notes, the IASB and the FASB developed a new lease accounting model that required lessees to recognize both finance leases and operating leases on their balance sheet (FASB, 2016; IASB, 2009, 2010, 2013, 2016). However, this study finds that capital market participants consider disclosed operating lease information in assessing firms' credit risk when this information is reliable. These results suggest that requiring lessees to recognize all leases on their balance sheet might not be necessary when complete information about operating leases is provided in the notes to financial statements.

The remainder of this paper is organized as follows. Section 2 summarizes accounting for leases in Japan, reviews prior research, and develops hypotheses. Section 3 explains 
my research design, including the constructive capitalization method to capitalize operating leases and the research model to investigate the risk relevance of operating leases. Section 4 provides the reasons for selecting the samples and reports the descriptive statistics of the variables of this empirical research. Section 5 shows the effects of constructively capitalizing operating leases on credit ratings. Section 6 provides the conclusions and discusses the limitations of this research.

\section{Background and Hypothesis Development}

\subsection{Accounting for Leases in Japan}

In June 1993, the Business Accounting Council (BAC) issued the lease accounting standard, Statement of Opinions on Accounting Standards for Lease Transactions (BAC, 1993). The Statement classified leases as either finance leases or operating leases and required the following accounting treatments: finance leases were recognized on lessees' balance sheet and operating leases were not recognized on their balance sheet.

In Japan, finance leases are classified into two further categories: finance leases that transfer ownership to lessees (FLO) and finance leases that do not transfer ownership to lessees (FLNO). ${ }^{1}$ In principle, Japanese firms are required to recognize finance leases on their balance sheet. However, the BAC allowed Japanese firms not to recognize FLNO on their balance sheet if information equivalent to the capitalization of finance leases was disclosed in the notes to financial statements. Almost all Japanese firms chose this offbalance sheet treatment. ${ }^{2}$

\footnotetext{
1 In January 1994, the Japanese Institute of Certified Public Accountants (JICPA) issued the implementation guidance, Practical Guidelines on Accounting Standards for, and Disclosure of, Lease Transactions (JCPA, 1994). The JICPA stated the following criteria to classify leases as either finance leases or operating leases: (a) transfer of the ownership term, (b) grant of the right to purchase term, (c) custom-made or custom-built assets, (d) present value criterion, and (e) useful economic life criterion. If leases satisfy any of these criteria, they are classified as finance leases; otherwise, they are classified as operating leases. Furthermore, finance leases that meet any of the criteria indicated in (a), (b), or (c) are classified as FLO and as FLNO otherwise (JICPA, 1994).

2 The Japan Leasing Association (JAL) found that 99.7\% of Japanese listed companies that prepared consolidated financial statements following Japanese GAAP chose the off-balance sheet treatment when accounting for finance leases (JAL, 2003).
} 
In 2002, the Accounting Standards Board of Japan (ASBJ), which was established in 2001 as a private standard setter, started considering whether the off-balance sheet treatment should be repealed to implement the global convergence of accounting standards. The ASBJ deliberated on this issue for four years and finally issued Statement No. 13 in March 2007. Statement No. 13 requires lessees to recognize all finance leases, namely both FLO and FLNO, on their balance sheet. However, Statement No. 13 requires lessees not to recognize operating leases on their balance sheet. Statement No. 13 is very similar to IFRS (IAS 17) and U.S. GAAP (ASC 840/SFAS 13). Statement No. 13 was mandatorily adopted for fiscal years beginning on or after April 1, 2008. ${ }^{3}$

Before the adoption of Statement No. 13, Japanese firms were more likely to use finance leases than operating leases (Kusano et al., 2015). One of the reasons is that they were allowed not to recognize finance leases on their balance sheet. However, Statement No. 13 requires lessees to recognize all finance leases on their balance sheet. Accordingly, they are more likely to use operating leases than finance leases after adopting Statement No. 13. In fact, previous studies find a systematic substitution of finance leases with operating leases in response to the adoption of Statement No. 13 (Arata, 2012; Kusano, Sakuma, \& Tsunogaya, 2016; Yamamoto, 2010). Considering these circumstances, investigating the impacts of capitalizing operating leases for a sample of Japanese firms is extremely valuable.

\subsection{Prior Literature}

Prior experimental and survey research has investigated the effects of presentation format on financial statement users' decisions (e.g., Libby \& Emett, 2014; Spencer \& Webb, 2015). For instance, using lease arrangements, prior literature analyzes whether bankers and analysts consider disclosed information when making decisions, and whether they process disclosed items in notes similarly with recognized obligations in financial statements (e.g.,

\footnotetext{
${ }^{3}$ Early adoption of Statement No. 13 was permitted for fiscal years beginning on or after April 1, 2007.
} 
Durocher \& Fortin, 2009; Gopalakrishnan \& Parkash, 1996; Krische, Sanders, \& Smith, 2014; Munter \& Ratcliffe, 1983; Nelson \& Tayler, 2007; Wilkins \& Zimmer, 1983a, 1983b). Prior archival research likewise examines whether and how capital market participants consider disclosed information in their decision making.

Previous studies examines the theoretical relationships between firms' leverage (operating leverage and financial leverage) and equity risk and empirically analyzes these relationships (e.g., Beaver, Kettler, \& Scholes, 1970; Bowman, 1979; Christie, 1982; Hamada, 1969, 1972; Modigliani \& Miller, 1958; Rubinstein, 1973). In particular, prior literature investigates whether capital market participants use not only recognized amounts in financial statements but also disclosed financial information in the notes to financial statements when assessing firms' risk (e.g., Bowman, 1980).

Previous studies report that capital market participants amend firms' leverage using disclosed operating leases and employ this leverage when assessing equity risk (Beattie et al., 2000; Bratten et al., 2013; Dhaliwal et al., 2011; Ely, 1995; Ge et al., 2008; Imhoff et al., 1993). For instance, Ely (1995) shows that estimated operating lease obligations are associated with equity risk using the standard deviations of stock returns. However, in Japan, Shimizu and Yoshida (2016) find that constructively capitalized operating leases are not risk relevant in explaining equity risk.

In addition, prior literature examines whether off-balance sheet operating leases have the same risk relevance in explaining equity risk as recognized obligations in financial statements (Bratten et al., 2013; Dhaliwal et al., 2011). For example, Bratten et al. (2013) report that capital market participants consider disclosed operating leases and recognized finance leases similarly when assessing equity risk. In contrast, Dhaliwal et al. (2011) show that the risk relevance of disclosed operating leases is substantially different from the risk relevance of recognized finance leases.

Currently, prior literature investigates the associations between operating leases and credit risk, in addition to equity risk. Previous studies report that constructively capitalized operating leases using footnote information are associated with the cost of debt 
(Altamuro et al., 2014; Andrade et al., 2014; Bratten et al., 2013; Chu et al., 2008; Kraft, 2015; Lim et al., 2014; Sengupta \& Wang, 2011). For instance, Bratten et al. (2013) show that operating leases are risk relevant in explaining the debt yield spread and document that the associations between finance lease obligations versus operating lease obligations and the cost of debt are not substantially different. However, when operating lease disclosures are less reliable, they report that the associations between recognized finance leases versus disclosed operating leases and the cost of debt are substantially different. Their results indicate that the reliability of accounting information has significant effects on the risk relevance of operating leases.

In summary, many previous studies find that capital market participants sufficiently understand off-balance sheet operating leases and consider them when assessing firms' equity and credit risks. Although operating leases are risk relevant, prior literature provides mixed evidence on the associations between firms' risk and disclosed operating leases versus recognized obligations. Furthermore, firms' information environment, such as the reliability of accounting information, has substantial effects on the risk relevance of operating leases. However, when operating lease information is not sufficiently disclosed, whether or not sophisticated capital market participants consider operating lease disclosures when assessing firms' risk is uncertain. Accordingly, using a sample of Japanese firms, this study investigates the effects of capitalizing operating leases to fill the gap in the prior literature.

\subsection{Hypothesis Development}

Capital market participants assess firms' risk using accounting information, including recognized amounts in financial statements and disclosed financial information in the notes. If off-balance sheet operating leases substantially affect firms' credit risk, capital market participants would incorporate these leases into their decision making regardless of accounting treatment. In fact, prior literature shows that off-balanced operating leases are risk relevant in explaining credit risk (Altamuro et al., 2014; Andrade et al., 2014; 
Bratten et al., 2013; Chu et al., 2008; Kraft, 2015; Lim et al., 2014; Sengupta \& Wang, 2011).

However, even though capital market participants use both accounting information recognized in financial statements and financial information disclosed in the notes, operating lease disclosures may not provide them with useful information. When operating lease information is not sufficiently disclosed in the notes to financial statements, capital market participants may have difficulty understanding and using operating lease disclosures. In fact, operating lease disclosures under Japanese GAAP are insufficient compared with those under IFRS and U.S. GAAP. Regarding operating leases, Japanese GAAP requires lessees to disclose in the notes to the financial statements only future minimum lease payments divided between within one year and more than one year out. For instance, Shimizu and Yoshida (2016) report that constructively capitalized operating leases are not associated with equity risk. Their result indicates that equity investors do not understand or might not use operating lease information when assessing firms' risk. ${ }^{4}$ However, the risk relevance of operating leases depends on the extent to which disclosed information has been processed by various capital market participants. Compared with the average equity investor, credit rating agencies are more sophisticated at processing financial information to evaluate firms' credit risk.

Thus, it is necessary to empirically investigate whether a credit rating agency considers operating lease information when it is not sufficiently disclosed. Accordingly, I develop the following hypothesis to examine the associations between operating lease obligations and credit risk (stated in the alternative form):

Hypothesis 1: Constructively capitalized operating lease obligations are associated with the cost of debt.

Even though operating leases are associated with credit risk, whether the associations

\footnotetext{
4 Shimizu and Yoshida (2016) estimate operating lease obligations using a present value method to analyze the risk relevance of operating leases. Equity investors might not use a present value method but use a multiple method to constructively capitalize operating leases.
} 
between the cost of debt and operating leases versus finance leases are substantially similar is uncertain because the reliability of accounting information may differ between operating leases and finance leases. In Japan, until the adoption of Statement No. 13, Japanese firms are allowed not to recognize finance leases on their balance sheet if they disclose information equivalent to capitalization of finance leases. Accordingly, the amounts of finance lease obligations are disclosed in the notes to financial statements. Capital market participants can directly use the finance lease obligation amounts to assess firms' risk; however, they have to estimate the value of operating lease obligations using footnote information. Thus, measurement errors related to finance lease obligations are less likely to occur compared to operating lease obligations.

In addition, Statement No. 13 requires lessees to recognize finance leases on their balance sheet. ${ }^{5}$ Prior literature reports that the reliability of accounting information is different between recognition in financial statements and disclosure in the notes (Bratten et al., 2013; Callahan, Smith, \& Spencer, 2013; Cotter \& Zimmer, 2003; Davis-Friday, Liu, \& Mittelstaedt, 2004; Müller et al., 2015). This is because firm managers and auditors are more likely to scrutinize recognized amounts in financial statements than disclosed information in the notes (Clor-Proell \& Maines, 2014; Cotter \& Zimmer, 2003; Goncharov, Riedl, \& Sellhorn, 2014). The differences in managers' and auditors' attitudes between recognized and disclosed items create differences in the reliability of accounting information.

Thus, examining whether the risk relevance of leases is substantially different between operating leases and finance leases is necessary. Accordingly, I develop the following hypothesis to investigate the associations between operating leases versus finance leases and the cost of debt (stated in the null form):

\footnotetext{
5 When Statement No. 13 was issued, the ASBJ also issued Guidance No. 16, Guidance on Accounting Standard for Lease Transactions (ASBJ, 2007b). In principle, Statement No. 13 requires lessees to retroactively recognize all finance leases, namely both FLO and FLNO, on their balance sheet. However, Guidance No. 16 permits an important exceptional treatment: Japanese firms are allowed not to recognize on their balance sheet FLNO contracted before the initial adoption of Statement No. 13.
} 
Hypothesis 2: There is no difference in the risk relevance of operating lease obligations and finance lease obligations.

Even though capital market participants consider operating lease information when assessing firms' credit risk, constructively capitalized operating lease obligations are less risk relevant when operating lease disclosures are less reliable. Previous studies show that the reliability of accounting information has significant effects on value and risk relevance (e.g., Bratten et al., 2013; Callahan et al., 2013; Cotter \& Zimmer, 2003; Davis-Friday et al., 2004; Müller et al., 2015). It is predicted that the risk relevance of operating leases depends on the extent to which the estimated values of operating lease obligations are variable given the remaining lease contract lifetime. Because this study estimates the value of operating lease obligations using future minimum lease payments, the lengthening of the lease contract lifetime results in measurement errors related to operating lease obligations, thereby decreasing the reliability of accounting information. In fact, Bratten et al. (2013) show that the remaining lease contract lifetime has substantial effects on the measurement errors of operating lease obligations, thereby decreasing the risk relevance of operating leases.

Because Statement No. 13 requires Japanese firms to recognize finance leases on their balance sheet, they transfer leases from finance leases to operating leases in response to the adoption of Statement No. 13 (Arata, 2012; Kusano et al., 2016; Yamamoto, 2010). Moreover, Japanese firms are more likely to use operating leases than finance leases (Kusano et al., 2015), resulting in a lengthening of the lease contract lifetime of operating leases. It is predicted that the reliability of accounting information is more likely to affect the risk relevance of operating leases after the adoption of Statement No. 13.

Thus, investigating the effects of the reliability of accounting information on the risk relevance of operating leases is necessary. Accordingly, I develop the following hypothesis to analyze the associations between operating lease obligations and the cost of debt when operating lease information is less reliable (stated in the alternative form):

Hypothesis 3: The reliability of accounting information affects the risk relevance of 
operating lease obligations.

\section{Research Design}

\subsection{Constructive Capitalization Model}

Estimating the value of operating lease obligations is necessary when investigating the risk relevance of operating leases. Many previous studies use the present value method developed by Imhoff, Lipe, and Wright (1991) to estimate the value of operating lease obligations. However, estimating Japanese firms' operating lease obligations using the present value method is difficult because operating lease disclosures under Japanese GAAP are insufficient compared with those under IFRS and U.S. GAAP. Kusano et al. (2015) amend the present value method developed by Imhoff et al. (1991) and estimate operating lease obligations using operating lease disclosures under Japanese GAAP. Accordingly, following Kusano et al. (2015), I constructively capitalize operating leases as follows.

First, estimating the remaining lease contract lifetime (RL) of operating leases is necessary. This study calculates the RL for each firm and each fiscal year by dividing future minimum lease payments (total) by future minimum lease payments (within one year). In addition, the discount rate is necessary to estimate operating lease obligations using the present value method. Following previous studies (e.g., Bennett \& Bradbury, 2003; Durocher, 2008; Fülbier, Silva, \& Pferdehirt, 2008; Imhoff et al., 1993), I use the firmspecific discount rate to capitalize operating leases. ${ }^{6}$ I assume that no lease payment exists at the inception of the lease term. Capitalizing future minimum lease payments (within one year) $\left(\mathrm{FMLP}_{\mathrm{s}}\right)$ with the RL and the discount rate $(\mathrm{r})$, the value of operating lease obligations at the end of the fiscal year is $\frac{F M L P_{s}}{r} \times\left[1-(1+r)^{-R L}\right]$. Using the

${ }^{6}$ I calculate the firm-specific discount rate as follows. If I obtain the interest rate of finance leases disclosed in the supplementary statements, I use it as the discount rate. If the interest rate of finance leases is not disclosed in the supplementary statements, I calculate it using footnote information as follows: this year's interest expenses of finance leases are divided by the average amounts of last year's and this year's equivalent of year-end balance of lease payment payable. If I cannot obtain the interest rate of finance leases, I use the average interest rate of long-term debt as the discount rate. 
aforementioned method, this study estimates operating lease obligations and examines the impacts of constructively capitalized operating leases on credit ratings.

\subsection{Research Model for Testing Hypotheses}

To test Hypotheses 1 and 2, this study examines whether capital market participants consider disclosed operating leases when assessing firms' credit risk and process operating leases and finance leases similarly when setting the cost of debt. Prior literature uses credit ratings as a proxy for the cost of debt and examines the effects of constructively capitalizing operating leases on the cost of debt (Lim et al., 2014; Sengupta \& Wang, 2011). Thus, this research investigates the associations between operating lease obligations and credit ratings by estimating the following regression model:

Rating $_{i, t+1}=\alpha_{0}+\alpha_{1}$ Debt $_{i, t}+\alpha_{2} F_{L O} O_{i, t}+\alpha_{3} O L O_{i, t}+\alpha_{4}$ Size $_{i, t}+\alpha_{5} R O A_{i, t}+$ $\alpha_{6}$ Tangibility $_{i, t}+\alpha_{7}$ DMATURE $_{i, t}+\sum$ Industry Dummy $+\sum$ Year Dummy $+\varepsilon$

where Rating is Rating and Investment Information Inc.'s (R\&I's) issuer credit ratings that are initial issued or amended for fiscal year $t+1$, and the ratings are converted into numerical values from 1 (AAA) to 21 (D)7; Debt is debt divided by the book value of equity at the end of fiscal year t; FLO is finance lease obligations divided by the book value of equity at the end of fiscal year t; OLO is operating lease obligations divided by the book value of equity at the end of fiscal year t; Size is the natural log of sales for fiscal year t; ROA is ordinary income divided by total assets at the end of fiscal year t; Tangibility is tangible assets divided by total assets at the end of fiscal year t; DMATURE is operating cash flows divided by debt at the end of fiscal year $t$.

I estimate regression model (1) using ordinary least squares (OLS) and standard

\footnotetext{
7 R\&I's issuer credit ratings have nine categories from AAA (highest category) to D (lowest category): AAA, AA, A, BBB, BB, B, CCC, CC, and D. R\&I adds a plus (+) or a minus (-) sign to the categories from $\mathrm{AA}$ to $\mathrm{CCC}$ to indicate relative standing within each rating category. Accordingly, R\&I's issuer credit ratings have 21 levels, and thus this study assigns the ratings to numerical rankings from 1 (AAA) to 21 (D). Following Ashbaugh-Skaife, Collins, and LaFond (2006), this study also reclassifies the ratings into seven categories from 1 (AAA) to 7 (CCC or lower rating category) and analyzes the risk relevance of operating leases. I show these results in Section 5.2.
} 
errors clustered by firm. ${ }^{8}$ Hypothesis 1 predicts that operating lease obligations are positively associated with credit ratings. That is, a larger OLO results in a higher Rating because firms with a high reliance on operating leases are expected to have higher credit risk. Thus, the sign of the coefficient in the regression model will be positive $\left(\alpha_{3}>0\right)$. In addition, similar to operating lease obligations, firms with a higher reliance on debt and finance lease obligations are expected to have higher credit risk and lower credit ratings. Accordingly, the signs of the coefficients of Debt and FLO are expected to be positive.

Next, Hypothesis 2 predicts that operating lease obligations and finance lease obligations have similar associations with credit ratings. Although the reliability of accounting information would be different between operating leases and finance leases, capital market participants carefully consider these leases in their decision making. Thus, the relationship between the coefficients in the regression model is expected to be $\alpha_{2}=$ $\alpha_{3}$. This study tests this prediction using the Wald test and the Likelihood Ratio (LR) test of equality between $\alpha_{2}$ and $\alpha_{3}$.

This study includes control variables for credit ratings. Because previous studies report that leverage, firm size, profitability, and asset tangibility are correlated with credit ratings (e.g., Ashbaugh-Skaife, Collins, \& LaFond, 2006; Horrigan, 1966; Kaplan \& Urwitz, 1979; Kraft, 2015), in addition to leverage (Debt and FLO), this study employs firm size (Size), profitability (ROA), and asset tangibility (Tangibility) as control variables. ${ }^{9}$ Because larger firms, more profitable firms, and firms with more tangible assets are less likely to be financially constrained, they are expected to have lower credit risk and, thus, higher credit ratings. Accordingly, Size, ROA, and Tangibility are expected to have

\footnotetext{
8 Because the dependent variable is a categorical variable, estimating the regression model using ordered logit or ordered probit might be a better approach. However, when we employ ordered logit (and ordered probit) regression, satisfying the assumption that the slope coefficients are the same in each binary regression is necessary: the parallel regression assumption. This study also uses ordered logit regression to examine the effects of capitalizing operating leases on credit ratings. The unreported results are consistent with my findings estimated using OLS.

9 This study also includes a negative earnings dummy to control for firms' default risk. The unreported results show that including this control variable does not change my main results and the coefficients of the variable are not statistically significant.
} 
negative coefficients in the regression model. Furthermore, when credit rating agencies determine credit ratings, they consider not only profitability, size, and financial policy but also financial strength regarding whether firms can redeem their debt within a reasonable period (e.g., Altamuro et al., 2014; Goto, 2013; Kraft, 2015; R\&I, 2015). This study includes the inverse ratio of years to debt maturity (DMATURE) in the regression model to control for differences in firms' debt structure. Longer years to debt maturity result in higher credit risk and lower credit ratings. Thus, I expect that the sign of the coefficient of DMATURE will be negative. Finally, to control for market conditions, I include Industry Dummy and Year Dummy as control variables into regression model (1).10

To test Hypothesis 3, this study investigates the effects of the reliability of accounting information on the risk relevance of operating leases. Following Bratten et al. (2013), this study uses the remaining lease contract lifetime of operating leases as a proxy for the reliability of accounting information. Accordingly, this research investigates how a credit rating agency considers operating lease information when determining credit ratings by estimating the following regression model:

$$
\begin{aligned}
& \text { Rating }_{i, t+1}=\beta_{0}+\beta_{1} \text { Debt }_{i, t}+\beta_{2} \mathrm{FLO}_{i, t}+\beta_{3} O L O_{i, t}+\beta_{4} O L O_{i, t} \times \text { Reliability }+ \\
& \beta_{5} \text { Size }_{i, t}+\beta_{6} \text { ROA }_{i, t}+\beta_{7} \text { Tangibility }_{i, t}+\beta_{8} \text { DMATURE }_{i, t}+\sum \text { Industry Dummy }+ \\
& \sum \text { Year Dummy }+\epsilon
\end{aligned}
$$

where Reliability is the normalization of the remaining lease contract lifetime of operating leases by fiscal year; OLO $\times$ Reliability is an interaction term between OLO and Reliability at the end of fiscal year t; all other variables are already defined in equation (1).

This study predicts that lengthening the remaining lease contract lifetime induces measurement errors related to operating lease obligations, thereby decreasing the risk relevance of operating leases. Accordingly, the sign of the coefficient of OLO $\times$ Reliability is expected to be negative $\left(\beta_{4}<0\right)$. The signs of the coefficients of all other variables in regression model (2) are the same as those in regression model (1).

\footnotetext{
10 This study defines industries using the Nikkei industry classification of 36 industries (Nikkei gyosyu chu-bunrui).
} 


\section{Sample Selection and Descriptive Statistics}

The sample of listed firms that adopt Japanese GAAP is selected using the following criteria:

(i) From April 2000 to March 2014, R\&I issues or amends the issuer credit rating.

(ii) Banks, securities firms, insurance, and other financial firms are deleted.11

(iii) Fiscal year ends on March $31 .{ }^{12}$

(iv) The accounting period has not changed during the fiscal year.

(v) The necessary data on financial statements and credit ratings are available from the respective databases subsequently mentioned.

The data on issuer credit ratings are obtained from the database provided by R\&I. If the credit rating agency issues or amends the issuer credit rating for a firm several times during the fiscal year, this study uses the first issued or amended issuer credit rating. In addition, this study collects data on consolidated financial statements from the Nikkei NEEDS Financial QUEST database. The full-fledged data on leases in consolidated financial statements are available only after 2000. Thus, this study's sample period starts in 2000. Credit ratings data must be matched with financial statements data. If R\&I issues or amends the issuer credit rating for fiscal period $t$, then financial statements data for fiscal period $t-1$ are matched with credit ratings data.

Using the aforementioned criteria, this study obtains an initial sample of 3,857 observations of consolidated financial statements and credit ratings data. This study requires both finance leases and operating leases. In particular, because the data for investigating the risk relevance of capitalizing operating leases are necessary, firms that lack data on future minimum lease payments for operating leases and the discount rate to capitalize operating leases are deleted from the sample. Both types of leases are

\footnotetext{
11 This study excludes firm-year observations for finance institutions because they tend to be net lessors.

12 Because most Japanese firms end their fiscal year on March 31, this study uses Japanese firms with a fiscal-year end on March 31.
} 
available for the sample of 2,429 firm-year observations. ${ }^{13}$ Furthermore, in order to control for outliers, the top and bottom $1 \%$ of the continuous accounting variables are trimmed by year. The final sample consists of 2,048 firm-year observations.

$<$ Insert Table 1>

Table 1 presents the descriptive statistics for the variables used in this study. Panel A of Table 1 reports the descriptive statistics for the sample of all firms in this study. It shows that the mean (median) of Rating, which is R\&I's issuer credit rating, is 6.6943 (7.0000). The panel also reports that the mean (median) of OLO, which is operating lease obligations, is 0.0380 (0.0099). In addition, the mean (median) of FLO, which is finance lease obligations, is 0.0339 (0.0151). These results indicate that the use of operating leases is more likely to be skewed than that of finance leases.

Panel B of Table 1 shows the descriptive statistics for the variables divided between pre-Statement No. 13 and post-Statement No. 13 adoption. The mean and median differences in OLO, 0.0063 and 0.0049 , are positive and statistically significant. The results indicate that firms are more likely to use operating leases after the adoption of Statement No. 13. In contrast, the mean and median differences in FLO are negatively and statistically significant at the $1 \%$ level. These results suggest that Japanese firms transfer leases from finance leases to operating leases in response to the adoption of Statement No. 13 (Arata, 2012; Kusano et al., 2016; Yamamoto, 2010).

\section{$<$ Insert Table 2>}

Table 2 describes the correlation matrix for the variables used in this study. The upper right-hand area of the table reports the Spearman rank-order correlations, and the lower left-hand area of the table reports the Pearson correlations. In both correlation analyses, OLO is positively and significantly associated with Rating. These results indicate that operating lease obligations are associated with credit ratings, as predicted. Most of the

\footnotetext{
${ }^{13}$ I check whether a sample of firms with finance leases and operating leases has negative total assets or a negative book value of equity. The sample of firms has neither negative total assets nor a negative book value of equity.
} 
correlations between independent variables are relatively low. ${ }^{14}$

\section{Results}

\subsection{Main Results}

First, this study examines whether capital market participants sufficiently understand off-balance sheet operating leases and consider them when assessing firms' credit risk. To test Hypothesis 1, this research analyzes the risk relevance of operating lease obligations using regression model (1). Table 3 reports the results for Hypothesis 1 using OLS. Industry and year fixed effects are included but are not tabulated.

\section{$<$ Insert Table 3>}

Column (1) of Table 3 shows the result for a sample of all firms in this study. The coefficient of OLO, 2.4449, is positive and statistically significant, as predicted. This result indicates that capital market participants incorporate disclosed operating leases when assessing firms' credit risk. Accordingly, the evidence supports Hypothesis 1.

In addition, this study divides the sample period between pre-Statement No. 13 and post-Statement No. 13 adoption and tests Hypothesis 1. Statement No. 13 requires Japanese firms to recognize finance leases on their balance sheet. Capital market participants might change their risk assessment in response to the adoption of Statement No. 13. Column (2) presents the result for pre-Statement No. 13 adoption. The coefficient of OLO is consistent with the expected sign and statistically significant at the $1 \%$ level. This result also supports Hypothesis 1 . In column (3), this study reports the result for postStatement No. 13 adoption. The coefficient of OLO, 1.2074, is positive but not statistically significant. The evidence indicates that off-balance sheet operating leases provide useful information to capital market participants before, but do not do so after, the adoption of Statement No. 13. This study subsequently analyzes these results in greater detail.

\footnotetext{
14 Table 2 shows that the coefficient between Debt and DMATURE is -0.7660 (Spearman rank-order correlation). When I estimate the regression models using OLS, I calculate the variance inflation factor (VIF). The values of VIF are less than 10. The results suggest that the effects of multicollinearity are not concerned.
} 
Next, this study investigates whether capital market participants use disclosed operating leases and finance leases similarly in setting credit ratings. Using the Wald test and the LR test, this research examines the equality of the coefficients of OLO and FLO. Table 4 reports the results for Hypothesis 2.

\section{$<$ Insert Table 4>}

Column (1) of Table 4 shows the result for a sample of all firms and column (2) reports the result for the pre-Statement No. 13 adoption, respectively. The Wald tests show that the coefficients of OLO are not statistically different from the coefficients of FLO. In addition, the LR tests report that the coefficients of OLO are statistically similar to the coefficients of FLO. These results indicate that the associations between operating leases versus finance leases and credit ratings are not substantially different. The evidence supports Hypothesis 2. However, column (3) presents the result for post-Statement No. 13 adoption, which shows that the coefficients of OLO are significantly different from the coefficients of FLO. In particular, the LR test reports that the coefficient of OLO is statistically different from the coefficient of FLO at the 1\% level. This result indicates that, after the adoption of Statement No. 13, capital market participants process operating leases differently from finance leases when assessing firms' credit risk.

Lastly, when operating lease disclosures are not reliable, this study investigates how capital market participants consider disclosed operating leases when setting the cost of debt. To test Hypothesis 3, this research analyzes the effects of the reliability of accounting information on the risk relevance of operating lease obligations using regression model (2). Table 5 summarizes the results for Hypothesis 3 using OLS.

\section{$<$ Insert Table 5>}

Column (1) of Table 5 reports the result for a sample of all firms and column (2) shows the result for the pre-Statement No. 13 adoption, respectively. The coefficients of OLO are consistent with the expected sign and statistically significant. Moreover, the coefficients of OLO $\times$ Reliability are negative and statistically significant, as predicted. These results indicate that operating leases are risk relevant; however, lengthening the remaining lease 
contract lifetime induces measurement errors related to operating lease obligations, thereby decreasing the risk relevance of operating leases. The evidence supports Hypothesis 3.

Column (3) presents the results for post-Statement No. 13 adoption. The coefficient of OLO, 3.7990, is positive and statistically significant at the $1 \%$ level. In addition, the coefficient of $\mathrm{OLO} \times$ Reliability, -5.6455 , is negative and statistically significant, as predicted. These results show that constructively capitalized operating leases are risk relevant when operating lease disclosures are reliable. The result also supports Hypothesis 3, which states that the reliability of accounting information has substantial effects on the risk relevance of operating leases. Furthermore, this study analyzes the equality of the coefficients of OLO $\times$ Reliability between pre-Statement No. 13 and postStatement No. 13 adoption. An unreported result shows a chi-square value ( $p$-value) of 3.62 (0.0569). 15 The result indicates that the reliability of accounting information is more likely to affect the risk relevance of operating leases after the adoption of Statement No. 13. ${ }^{16}$ The evidence is consistent with capital market participants placing less weight on less reliable operating lease information when assessing credit risk.

In summary, this study finds that operating leases are associated with credit ratings. Moreover, operating leases and finance leases are processed similarly when determining credit ratings. However, after the adoption of Statement No. 13, this research reports that operating leases are not risk relevant in explaining credit risk; moreover, the associations between operating leases versus finance leases and credit ratings are different. The results

\footnotetext{
15 To analyze the equality of the coefficients of OLO $\times$ Reliability between pre-Statement No. 13 and post-Statement No. 13 adoption, this study simultaneously regresses equation (2) in pre-Statement No. 13 and post-Statement No. 13 and uses the Wald test.

16 This study investigates the mean and median differences in the remaining lease contract lifetime of operating leases between pre-Statement No. 13 and post-Statement No. 13 adoption. The unreported results show that the mean and median differences in the remaining lease contract lifetime are positively and statistically significant. That is, the remaining lease contract lifetime of operating leases after the adoption of Statement No. 13 is significantly longer than that before the adoption of Statement No. 13. These results indicate that lengthening the lease contract lifetime results in a decrease in the risk relevance of operating leases. The results suggest that Statement No. 13 has significant effects on a credit rating agency when determining credit ratings.
} 
indicate that the risk relevance of operating leases decreases when Statement No. 13 is adopted. A decrease in the risk relevance of operating leases is predicted to be the result of lengthening the lease contract lifetime, thereby inducing the measurement errors of operating lease obligations. This study documents that the reliability of accounting information has significant effects on the risk relevance of operating leases, particularly after the adoption of Statement No. 13.

\subsection{Robustness Test}

The previous subsection documented that operating leases were associated with credit ratings and that the reliability of accounting information had significant effects on the risk relevance of operating leases. This subsection describes the analysis conducted to determine the robustness of my findings.

First, to examine whether my results are sensitive to the classification of credit ratings, following Ashbaugh-Skaife et al. (2006), this study reclassifies the ratings into seven categories from 1 (AAA) to 7 (CCC or lower rating category). The unreported results are consistent with my main findings that operating leases are risk relevant and have the same risk relevance as finance leases when operating lease disclosures are reliable; moreover, the reliability of accounting information affects the risk relevance of operating leases for explaining credit risk.

Next, to investigate whether my results are sensitive to the constructive capitalization method, this study uses a different present value method. This study employs the present value method developed by Imhoff et al. (1991) and estimates operating lease obligations. This present value method assumes that lease payment amounts are constant during the lease term when constructively capitalizing operating leases. However, when firms have multiple lease contracts made at different periods, the lease payment amounts gradually decrease because each contract expires over time. Assuming that the lease payment amounts are constant during the lease term would overestimate the value of the operating lease obligations. Ely (1995) proposes another present value method that assumes that 
lease payment amounts gradually decrease over time. Accordingly, following Ely (1995), this study estimates the value of operating lease obligations and reinvestigates the effects of capitalizing operating leases on credit ratings. The unreported results show that operating leases are risk relevant and have the same risk relevance as finance leases for explaining credit risk. Moreover, the reliability of accounting information has substantial effects on the risk relevance of operating leases.

In summary, even after using another reclassification of credit ratings and constructive capitalization method, the results do not change my main results. These results confirm the robustness of my findings.

\section{Concluding Remarks}

This study investigated whether and how capital market participants considered offbalance sheet operating leases when assessing firms' credit risk in Japan. In particular, this research examined that the credit rating agency constructively capitalized operating leases and used them in determining credit ratings. This study provided the following useful evidence on the impacts of capitalizing operating leases.

First, this study found that operating leases were associated with credit ratings. In addition, operating leases and finance leases were processed similarly when determining credit ratings. However, after the adoption of Statement No. 13, operating leases were not risk relevant, which was substantially different from the risk relevance of finance leases. This study reported that the reliability of accounting information had significant effects on the risk relevance of operating leases. These results indicate that capital market participants sufficiently understand off-balance sheet operating leases and consider them in assessing firms' credit risk when their disclosures are reliable.

Overall, this study documented the effects of capitalizing operating leases on credit ratings. Despite the valuable insights into the usefulness of operating lease disclosures, this study has several limitations. For instance, this study found that the reliability of accounting information had significant effects on the risk relevance of operating leases 
using the remaining lease contract lifetime as a proxy for reliable information. The IASB and the FASB issued new lease accounting standards that required lessees to recognize almost all leases, namely finance leases and operating leases, on their balance sheet (FASB, 2016; IASB, 2016). Considering these circumstances, examining whether and how firms' information environment, including the reliability of accounting information, affects the risk relevance of operating leases is necessary. Such an examination provides a more comprehensive understanding of the effects of capitalizing operating leases. 


\section{References}

Accounting Standards Board of Japan (ASBJ) (2007a). ASBJ Statement No. 13, Accounting Standard for Lease Transactions. ASBJ.

Accounting Standards Board of Japan (ASBJ) (2007b). ASBJ Guidance No. 16, Guidance on Accounting Standard for Lease Transactions. ASBJ.

Altamuro, J., Johnston, R., Pandit, S., \& Zhang, H. (2014). Operating leases and credit assessments. Contemporary Accounting Research, 31(2), 551-580.

Andrade, S. C., Henry, E., \& Nanda, D. (2014). The impact of operating leases and purchase obligations on credit market prices. Working Paper.

Arata, E. (2012). Economic consequences of revised accounting standard for leases: Effects on lessees' procurement behavior. Working Paper.

Ashbaugh-Skaife, H., Collins, D. W., \& LaFond, R. (2006). The effects of corporate governance on firms' credit ratings. Journal of Accounting and Economics, 42(1-2), 203243.

Barone, E., Birt, J., \& Moya, S. (2014). Lease accounting: A review of recent literature. Accounting in Europe, 11(1), 35-54.

Barth, M. E., Clinch, G., \& Shibano, T. (2003). Market effects of recognition and disclosure. Journal of Accounting Research, 41(4), 581-609.

Beattie, V., Goodacre, A., \& Thomson, S. (2000). Recognition versus disclosure: An investigation of the impact on equity risk using UK operating lease disclosures. Journal of Business Finance \& Accounting, 27(9-10), 1185-1224.

Beaver, W., Kettler, P., \& Scholes, M. (1970). The association between market determined and accounting determined risk measures. The Accounting Review, 45(4), 654-682.

Bennett, B. K., \& Bradbury, M. E. (2003). Capitalizing non-cancelable operating lease. Journal of International Financial Management and Accounting, 14(2), 101-114.

Bowman, R. G. (1979). The theoretical relationship between systematic risk and financial (accounting) variables. Journal of Finance, 34(3), 617-630.

Bowman, R. G. (1980). The debt equivalence of leases: An empirical investigation. The Accounting Review, 55(2), 237-253.

Bratten, B., Choudhary, P., \& Schipper, K. (2013). Evidence that market participants assess recognized and disclosed items similarly when reliability is not an issue. The Accounting Review, 88(4), 1179-1210.

Business Accounting Council (BAC) (1993). Statement of Opinions on Accounting Standards for Lease Transactions. BAC.

Callahan, C. M., Smith, R. E., \& Spencer, A. W. (2013). The valuation and reliability implications of FIN 46 for synthetic lease liabilities. Journal of Accounting and Public Policy, 32(4), 271-291.

Christie, A. A. (1982). The stochastic behavior of common stock variances: Value, leverage and interest rate effects. Journal of Financial Economics, 10(4), 407-432.

Chu, L., Levesque, T. J., Mathieu, R., \& Zhang, P. (2008). The impact of lease obligations on loan pricing. Working Paper. 
Clor-Proell, S. M., \& Maines, L. A. (2014). The impact of recognition versus disclosure on financial information: A preparer's perspective. Journal of Accounting Research, 52(3), 671-701.

Cotter, J., \& Zimmer, I. (2003). Disclosure versus recognition: The case of asset revaluations. Asia-Pacific Journal of Accounting and Economics, 10(1), 81-99.

Davis-Friday, P. Y., Liu, C. S., \& Mittelstaedt, H. F. (2004). Recognition and disclosure reliability: Evidence from SFAS No. 106. Contemporary Accounting Research, 21(2), 399-429.

Dhaliwal, D. S., Lee, H. S., \& Neamtiu, M. (2011). The impact of operating leases on firm financial and operating risk. Journal of Accounting, Auditing \& Finance, 26(2), 151-197.

Durocher, S. (2008). Canadian evidence on the constructive capitalization of operating Leases. Accounting Perspectives, 7(3), 227-256.

Durocher, S., \& Fortin, A. (2009). Proposed changes in lease accounting and private business bankers' credit decisions. Accounting Perspectives, 8(1), 9-42.

Ely, K. M. (1995). Operating lease accounting and the market's assessment of equity risk. Journal of Accounting Research, 33(2), 397-415.

Financial Accounting Standards Board (FASB) (1976). Statement of Financial Accounting Standards (SFAS) No. 13, Accounting for Leases. FASB.

Financial Accounting Standards Board (FASB) (2016). Accounting Standards Codification (ASC) Topic 842, Leases. FASB.

Fülbier, R. U., Silva, J. L., \& Pferdehirt, M. H. (2008). Impact of lease capitalization on financial ratios of listed German companies," Schmalenbach Business Review, 60(2), 122-144.

Ge, W., Imhoff, G., \& Lee, L. F. (2008). Is recognition for operating leases necessary? Working Paper.

Goncharov, I., Riedl, E. J., \& Sellhorn, T. (2014). Fair value and audit fees. Review of Accounting Studies, 19(1), 210-241.

Gopalakrishnan, V., \& Parkash, M. (1996). The debt equivalency of recognized vs. disclosed obligations: An examination of borrower and lender perceptions. Research in Accounting Regulation, 10, 63-77.

Goto, J. (2013). Financial statement analysis by credit analysts: Analyzing corporate credit risk. Accounting, 65(7), 40-47 (in Japanese).

Hamada, R. S. (1969). Portfolio analysis, market equilibrium and corporation finance. Journal of Finance, 24(1), 13-31.

Hamada, R. S. (1972). The effect of the firm's capital structure on the systematic risk of common stocks. Journal of Finance, 27(2), 435-452.

Horrigan J. O. (1966). The determination of long-term credit standing with financial ratios. Journal of Accounting Research, 4, 44-62.

Imhoff Jr., E. A., Lipe, R. C., \& Wright, D. W. (1991). Operating leases: Impact of constructive capitalization. Accounting Horizons, 5(1), 51-63.

Imhoff Jr., E. A., Lipe, R. C., \& Wright, D. W. (1993). The effects of recognition versus disclosure on shareholder risk and executive compensation. Journal of Accounting, 
Auditing \& Finance, 8(4), 335-368.

International Accounting Standards Board (IASB) (2009). Discussion Paper, Leases Preliminary Views. IASB.

International Accounting Standards Board (IASB) (2010). Exposure Draft, Leases. IASB. International Accounting Standards Board (IASB) (2013). Exposure Draft, Leases. IASB. International Accounting Standards Board (IASB) (2016). International Financial Reporting Standards (IFRS) No. 16, Leases. IASB.

International Accounting Standards Committee (IASC) (1982). International Accounting Standards (IAS) No. 17, Leases. IASC.

Japan Leasing Association (JAL) (2003). Disclosure of Lease Information and Impacts of Abolishment of "Off-Balance Sheet Treatment": Special Study on Revision of Lease Accounting Standard. JAL.

Japanese Institute of Certified Public Accountants (JICPA) (1994). Practical Guidelines on Accounting Standards for, and Disclosure of, Lease Transactions. JICPA.

Kaplan, R. S., \& Urwitz, G. (1979). Statistical models of bond ratings: A methodological inquiry. Journal of Business, 52(2), 231-261.

Kraft, P. (2015). Rating agency adjustments to GAAP financial statements and their effect on ratings and credit spreads. The Accounting Review, 90(2), 641-674.

Krische, S. D., Sanders, P. R., \& Smith, S. D. (2014). Management credibility and investment risk: An experimental investigation of lease accounting alternatives. Behavioral Research in Accounting, 26(1), 109-130.

Kusano, M., Sakuma, Y., \& Tsunogaya, N. (2015). Economic impacts of capitalization of operating leases: Evidence from Japan. Corporate Ownership and Control, 12(4), 838850.

Kusano, M., Sakuma, Y., \& Tsunogaya, N. (2016). Economic consequences of changes in the new lease accounting standard: Evidence from Japan. Journal of Contemporary Accounting \& Economics, 12(1), 73-88.

Libby, R., \& Emett, S. A. (2014). Earnings presentation effects on manager reporting choices and investor decisions. Accounting and Business Research, 44(4), 410-438.

Lim, S. C., Mann, S. C., \& Mihov, V. T. (2014). Market recognition of the accounting disclosure and economic benefits of operating leases: Evidence from borrowing costs and credit ratings. Working Paper.

Lipe, R. C. (2001). Lease accounting research and the G4+1 proposal. Accounting Horizons, 15(3), 299-310.

Lorensen, L. (1992). Accounting Research Monograph No. 4, Accounting for Liabilities. AICPA.

McGregor, W. (1996). Accounting for Leases: A New Approach, Recognition by Lessees of Assets and Liabilities Arising under Lease Contracts. FASB.

Michels, J. (2017). Disclosure versus recognition: Inferences from subsequent events. Journal of Accounting Research, 55(1), 3-34.

Modigiliani, F., \& Miller, M. H. (1958). The cost of capital, corporation finance and the theory of investment. The American Economic Review, 48(3), 261-297. 
Müller, M. A., Riedl, E. J., \& Sellhorn, T. (2015). Recognition versus disclosure of fair values. The Accounting Review, 90(6), 2411-2447.

Munter, P., \& Ratcliffe, T. A. (1983). An assessment of user reactions to lease accounting disclosures. Journal of Accounting, Auditing \& Finance, 6(2), 108-114.

Myers, J. H. (1962). Accounting Research Study (ARS) No. 4, Reporting of Leases in Financial Statements. AICPA.

Nailor, H., \& Lennard, A. (2000). Leases: Implementation of a New Approach. FASB.

Nelson, M. W., \& Tayler, W. B. (2007). Information pursuit in financial statement analysis: Effects of choice, effort, and reconciliation. The Accounting Review, 82(3), 731-758.

Rating and Investment Information, Inc. (R\&I) (2015). R\&I's Basic Methodology for Corporate Credit Ratings. R\&I.

Rubinstein, M. E. (1973). A mean-variance synthesis of corporate financial theory. Journal of Finance, 28(1), 167-181.

Schipper, K. (2007). Required disclosures in financial reports. The Accounting Review, 82(2), 301-326.

Sengupta, P., \& Wang, Z. (2011). Pricing of off-balance sheet debt: How do bond market participants use the footnote disclosures on operating leases and postretirement benefit plans? Accounting and Finance, 51(3), 787-808.

Shimizu, M., \& Yoshida, K. (2016). Analysis between lease obligations and equity risk in Japan. Securities Analysts Journal, 54(3), 65-75 (in Japanese).

Spencer, A. W., \& Webb, T. Z. (2015). Leases: A review of contemporary academic literature relating to lessees. Accounting Horizons, 29(4), 997-1023.

Wilkins, T., \& Zimmer, I. (1983a). The effects of alternative methods of accounting for leases: An experimental study. Abacus, 19(1), 64-75.

Wilkins, T., \& Zimmer, I. (1983b). The effect of leasing and different methods of accounting for leases on credit evaluations. The Accounting Review, 58(4), 749-764.

Yamamoto, T. (2010). Examination of the impact of changes to lease accounting standards on corporate behavior: Empirical analysis of manufacturing industry. Securities Analysts Journal, 48(2), 85-95 (in Japanese).

Yu, K. (2013). Does recognition versus disclosure affect value relevance? Evidence from pension accounting. The Accounting Review, 88(3), 1095-1127. 
Table 1: Descriptive Statistics

Panel A: Full Sample

\begin{tabular}{cccccccccc}
\hline & $\mathrm{N}$ & Mean & $\mathrm{SD}$ & $\mathrm{Min}$ & $\mathrm{p} 25$ & Median & $\mathrm{p} 75$ & $\mathrm{Max}$ \\
\hline \hline Rating & 2,048 & 6.6943 & 2.1816 & 1.0000 & 6.0000 & 7.0000 & 8.0000 & 14.0000 \\
Debt & 2,048 & 1.0386 & 1.0773 & 0.0011 & 0.3225 & 0.6953 & 1.3567 & 10.7935 \\
FLO & 2,048 & 0.0339 & 0.0493 & 0.0001 & 0.0064 & 0.0151 & 0.0411 & 0.5016 \\
OLO & 2,048 & 0.0380 & 0.0766 & 0.0000 & 0.0022 & 0.0099 & 0.0340 & 0.8755 \\
Size & 2,048 & 12.9036 & 1.1027 & 10.0691 & 12.0743 & 12.8902 & 13.8405 & 15.6733 \\
ROA & 2,048 & 0.0451 & 0.0332 & -0.0794 & 0.0230 & 0.0400 & 0.0641 & 0.1772 \\
Tangibility & 2,048 & 0.3604 & 0.1726 & 0.0600 & 0.2224 & 0.3386 & 0.4493 & 0.8673 \\
DMATURE & 2,048 & 0.7733 & 5.0978 & -0.8229 & 0.1242 & 0.2383 & 0.4840 & 203.6458 \\
\hline
\end{tabular}

Panel B: Pre-Statement No. 13 versus Post-Statement No. 13

\begin{tabular}{|c|c|c|c|c|c|c|c|c|}
\hline & \multicolumn{3}{|c|}{ Pre-Statement No. $13(\mathrm{~N}=1,089)$} & \multicolumn{3}{|c|}{ Post-Statement No. $13(\mathrm{~N}=959)$} & \multirow{2}{*}{$\begin{array}{c}\text { Mean } \\
\text { Difference }\end{array}$} & \multirow{2}{*}{$\begin{array}{c}\text { Median } \\
\text { Difference }\end{array}$} \\
\hline & Mean & SD & Median & Mean & SD & Median & & \\
\hline Rating & 6.8182 & 2.3393 & 7.0000 & 6.5537 & 1.9793 & 7.0000 & $-0.2645^{* k *}$ & 0.0000 \\
\hline Debt & 1.1142 & 1.2164 & 0.7002 & 0.9526 & 0.8863 & 0.6878 & $-0.1616^{\star \star \star *}$ & -0.0124 \\
\hline FLO & 0.0387 & 0.0552 & 0.0188 & 0.0285 & 0.0410 & 0.0120 & $-0.0101^{* * *}$ & $-0.0068^{* * *}$ \\
\hline OLO & 0.0351 & 0.0792 & 0.0083 & 0.0414 & 0.0733 & 0.0131 & $0.0063^{*}$ & $0.0049^{* * *}$ \\
\hline Size & 12.8603 & 1.1017 & 12.8443 & 12.9528 & 1.1022 & 12.9304 & $0.0925^{*}$ & 0.0861 \\
\hline ROA & 0.0491 & 0.0332 & 0.0433 & 0.0406 & 0.0326 & 0.0365 & $-0.0084^{* * *}$ & $-0.0068^{* * *}$ \\
\hline Tangibility & 0.3532 & 0.1627 & 0.3384 & 0.3687 & 0.1829 & 0.3388 & $0.0155^{\text {** }}$ & 0.0003 \\
\hline DMATURE & 0.8457 & 6.7410 & 0.2313 & 0.6911 & 1.9771 & 0.2476 & -0.1546 & 0.0163 \\
\hline
\end{tabular}

Notes:

Rating $=$ R\&I's issuer credit ratings that are initial issued or amended for fiscal year $t+1$; the ratings are converted into numerical values from 1 (AAA) to 21 (D)

Debt $=$ debt divided by the book value of equity at the end of fiscal year $t$ 
$\mathrm{FLO}=$ finance lease obligations divided by the book value of equity at the end of fiscal year $\mathrm{t}$

$\mathrm{OLO}=$ operating lease obligations divided by the book value of equity at the end of fiscal year $t$

Size $=$ the natural $\log$ of sales for fiscal year $\mathrm{t}$

$\mathrm{ROA}=$ ordinary income divided by total assets at the end of fiscal year $\mathrm{t}$

Tangibility $=$ tangible assets divided by total assets at the end of fiscal year $t$

DMATURE $=$ operating cash flows divided by debt at the end of fiscal year $t$

*k*k, ${ }^{* * *},{ }^{*}$ indicate that the coefficient estimate is significant at the $0.01,0.05$. and 0.1 levels using a two-tailed t test. 
Table 2: Correlation Matrix

\begin{tabular}{ccccccccc}
\hline & Rating & Debt & FLO & OLO & Size & ROA & Tangibility & DMATURE \\
\hline \hline Rating & 1.0000 & 0.3463 & 0.3442 & 0.0956 & -0.4400 & -0.2351 & -0.0335 & -0.3428 \\
& & $(0.0000)$ & $(0.0000)$ & $(0.0000)$ & $(0.0000)$ & $(0.0000)$ & $(0.1302)$ & $(0.0000)$ \\
Debt & 0.3177 & 1.0000 & 0.3125 & 0.2231 & 0.2372 & -0.5209 & 0.3834 & -0.7660 \\
& $(0.0000)$ &. & $(0.0000)$ & $(0.0000)$ & $(0.0000)$ & $(0.0000)$ & $(0.0000)$ & $(0.0000)$ \\
FLO & 0.2448 & 0.2519 & 1.0000 & 0.2078 & -0.0088 & -0.1007 & 0.1561 & -0.1679 \\
& $(0.0000)$ & $(0.0000)$ &. & $(0.0000)$ & $(0.6904)$ & $(0.0000)$ & $(0.0000)$ & $(0.0000)$ \\
OLO & 0.0904 & 0.2768 & 0.2843 & 1.0000 & 0.1150 & -0.0436 & 0.0569 & -0.1493 \\
& $(0.0000)$ & $(0.0000)$ & $(0.0000)$ &. & $(0.0000)$ & $(0.0486)$ & $(0.0100)$ & $(0.0000)$ \\
Size & -0.4403 & 0.2089 & 0.0185 & 0.1226 & 1.0000 & -0.0876 & -0.0109 & -0.0973 \\
& $(0.0000)$ & $(0.0000)$ & $(0.4017)$ & $(0.0000)$ &. & $(0.0001)$ & $(0.6221)$ & $(0.0000)$ \\
ROA & -0.2242 & -0.4247 & -0.0833 & -0.0661 & -0.0816 & 1.0000 & -0.1621 & 0.6098 \\
& $(0.0000)$ & $(0.0000)$ & $(0.0002)$ & $(0.0028)$ & $(0.0002)$ &. & $(0.0000)$ & $(0.0000)$ \\
Tangibility & -0.1178 & 0.3841 & 0.1136 & 0.1838 & -0.0063 & -0.1965 & 1.0000 & -0.1879 \\
& $(0.0000)$ & $(0.0000)$ & $(0.0000)$ & $(0.0000)$ & $(0.7742)$ & $(0.0000)$ &. & $(0.0000)$ \\
DMATURE & -0.0746 & -0.1127 & -0.0357 & -0.0301 & -0.0222 & 0.1560 & -0.0899 & 1.0000 \\
& $(0.0007)$ & $(0.0000)$ & $(0.1059)$ & $(0.1727)$ & $(0.3163)$ & $(0.0000)$ & $(0.0000)$ &. \\
\hline
\end{tabular}

Notes:

Pearson (Spearman) correlations are below (above) the diagonal.

All the variables are defined in Table 1.

$p$ values for correlation coefficients are reported in parentheses. 
Table 3: Results for Hypothesis 1

\begin{tabular}{|c|c|c|c|c|}
\hline & \multirow[b]{3}{*}{$\begin{array}{l}\text { Expected } \\
\text { Sign }\end{array}$} & (1) & (2) & (3) \\
\hline & & Full Period & $\begin{array}{c}\text { Pre-Statement } \\
\text { No. } 13\end{array}$ & $\begin{array}{c}\text { Post-Statement } \\
\text { No. } 13\end{array}$ \\
\hline & & $\begin{array}{c}\text { Coefficient } \\
\text { (t-value) }\end{array}$ & $\begin{array}{c}\text { Coefficient } \\
\text { (t-value) }\end{array}$ & $\begin{array}{c}\text { Coefficient } \\
\text { (t-value) }\end{array}$ \\
\hline \multirow[t]{2}{*}{ Constant } & & $20.7130^{* \star \star *}$ & $23.0231^{* * *}$ & $19.1641^{* * * *}$ \\
\hline & & (18.6902) & (17.2075) & (17.3858) \\
\hline \multirow[t]{2}{*}{ Debt } & + & $1.0928^{* * *}$ & $1.1042^{* * *}$ & $1.1825^{* * *}$ \\
\hline & & (11.7673) & $(9.6211)$ & (11.2046) \\
\hline \multirow[t]{2}{*}{ FLO } & + & $3.1148^{* *}$ & $2.5486^{*}$ & $5.0708^{* \star * *}$ \\
\hline & & $(2.1947)$ & (1.6860) & $(2.6168)$ \\
\hline \multirow[t]{2}{*}{ OLO } & + & $2.4449^{* \star * \star}$ & $3.1433^{\star \star \star \star *}$ & 1.2074 \\
\hline & & $(3.2510)$ & (3.1049) & (1.1349) \\
\hline \multirow[t]{2}{*}{ Size } & - & $-1.2140^{* \star *}$ & $-1.3966^{* \star *}$ & $-1.0257^{\star \star * k}$ \\
\hline & & $(-14.9012)$ & $(-14.2899)$ & $(-13.3977)$ \\
\hline \multirow[t]{2}{*}{ ROA } & - & $-8.4081^{* * *}$ & $-9.7430^{* * *}$ & $-6.0003^{* * *}$ \\
\hline & & $(-4.8093)$ & $(-3.8937)$ & $(-3.3497)$ \\
\hline \multirow[t]{2}{*}{ Tangibility } & - & $-1.3568^{*}$ & -1.1673 & $-1.5954^{*}$ \\
\hline & & $(-1.7442)$ & $(-1.2990)$ & $(-1.7927)$ \\
\hline \multirow[t]{2}{*}{ DMATURE } & - & $-0.0120^{* *}$ & $-0.0100^{* *}$ & -0.0210 \\
\hline & & $(-2.0344)$ & $(-1.9731)$ & $(-0.7622)$ \\
\hline Industry Dummy & & Yes & Yes & Yes \\
\hline Year Dummy & & Yes & Yes & Yes \\
\hline $\mathrm{N}$ & & 2,048 & 1,089 & 959 \\
\hline Adj. $R^{2}$ & & 0.699 & 0.730 & 0.681 \\
\hline
\end{tabular}

Notes:

All the variables are defined in Table 1.

Standard errors are clustered by firm. $t$ statistics are reported in parentheses. ${ }^{* * *},{ }^{* *},{ }^{*}$ indicate that the coefficient estimate is significant at the $0.01,0.05$. and 0.1 levels using a two-tailed t test. 
Table 4: Results for Hypothesis 2

\begin{tabular}{cccc}
\hline & $(1)$ & $(2)$ & $(3)$ \\
\cline { 2 - 4 } & Full Period & Pre-Statement & Post-Statement \\
& & No. 13 & No. 13 \\
\hline \hline Wald Test (OLO $=$ FLO) & 0.14 & 0.08 & 2.84 \\
& $(0.7114)$ & $(0.7754)$ & $(0.0930)$ \\
LR Test (OLO $=$ FLO) & 0.63 & 0.29 & 8.71 \\
& $(0.4283)$ & $(0.5888)$ & $(0.0032)$ \\
\hline
\end{tabular}

Notes:

All the variables are defined in Table 1.

The Wald tests and the LR tests report $\mathrm{F}$ statistics and chi-square values, respectively. $p$-values are reported in parentheses. 
Table 5: Results for Hypothesis 3

\begin{tabular}{|c|c|c|c|c|}
\hline & \multirow[b]{3}{*}{$\begin{array}{l}\text { Expected } \\
\text { Sign }\end{array}$} & (1) & (2) & (3) \\
\hline & & Full Period & $\begin{array}{c}\text { Pre-Statement } \\
\text { No. } 13\end{array}$ & $\begin{array}{c}\text { Post-Statement } \\
\text { No. } 13\end{array}$ \\
\hline & & $\begin{array}{c}\text { Coefficient } \\
\text { (t-value) }\end{array}$ & $\begin{array}{c}\text { Coefficient } \\
\text { (t-value) }\end{array}$ & $\begin{array}{l}\text { Coefficient } \\
\text { (t-value) }\end{array}$ \\
\hline \multirow[t]{2}{*}{ Constant } & & $20.7403^{* * *}$ & $22.8538^{* \star *}$ & $19.4290^{* * *}$ \\
\hline & & $(19.0904)$ & (17.1098) & (18.3374) \\
\hline \multirow[t]{2}{*}{ Debt } & + & $1.0911^{* * * *}$ & $1.0947^{\star * *}$ & $1.1921^{* * *}$ \\
\hline & & $(12.2422)$ & $(9.7257)$ & (11.9985) \\
\hline \multirow[t]{2}{*}{ FLO } & + & $3.0382^{* *}$ & 2.3864 & $4.8006^{* *}$ \\
\hline & & $(2.1885)$ & (1.6040) & $(2.5820)$ \\
\hline \multirow[t]{2}{*}{ OLO } & + & $4.8316^{* * *}$ & $5.6520^{* * *}$ & $3.7990^{* * *}$ \\
\hline & & $(4.0788)$ & $(2.6728)$ & (3.0349) \\
\hline \multirow[t]{2}{*}{ OLO $\times$ Reliability } & - & $-2.4803^{\star * *}$ & $-1.8711^{* *}$ & $-5.6455^{* * * *}$ \\
\hline & & $(-3.4577)$ & $(-1.9880)$ & $(-2.9816)$ \\
\hline \multirow[t]{2}{*}{ Size } & - & $-1.2185^{* * *}$ & $-1.3849^{* * * *}$ & $-1.0499^{* * *}$ \\
\hline & & $(-15.2686)$ & $(-14.1604)$ & $(-14.3311)$ \\
\hline \multirow[t]{2}{*}{$\mathrm{ROA}$} & - & $-8.0481^{* * * *}$ & $-9.3869^{* * *}$ & $-5.7461^{* * * *}$ \\
\hline & & $(-4.6516)$ & $(-3.7916)$ & $(-3.1733)$ \\
\hline \multirow[t]{2}{*}{ Tangibility } & - & $-1.2634^{*}$ & -1.0635 & -1.2711 \\
\hline & & $(-1.6661)$ & $(-1.1861)$ & $(-1.5328)$ \\
\hline \multirow[t]{2}{*}{ DMATURE } & - & $-0.0117^{* *}$ & $-0.0099^{* *}$ & -0.0192 \\
\hline & & $(-2.0587)$ & $(-1.9840)$ & $(-0.7090)$ \\
\hline Industry Dummy & & Yes & Yes & Yes \\
\hline Year Dummy & & Yes & Yes & Yes \\
\hline $\mathrm{N}$ & & 2,048 & 1,089 & 959 \\
\hline Adj. $R^{2}$ & & 0.705 & 0.734 & 0.692 \\
\hline
\end{tabular}

Notes:

Reliability $=$ the normalization of the remaining lease contract lifetime of operating leases by year OLO $\times$ Reliability $=$ an interaction term between OLO and Reliability

All other variables are defined in Table 1.

Standard errors are clustered by firm. $t$ statistics are reported in parentheses. ${ }^{* * *},{ }^{* *},{ }^{*}$ indicate that the coefficient estimate is significant at the $0.01,0.05$. and 0.1 levels using a two-tailed t test. 